Article

\title{
Anti-Corruption Movement: A Story of the Making of the Aam Admi Party and the Interplay of Political Representation in India
}

\author{
Aheli Chowdhury \\ Department of Sociology, Delhi School of Economics, University of Delhi, 11001 Delhi, India; \\ E-Mail: aheli.chowdhury@gmail.com
}

Submitted: 30 March 2019 | Accepted: 26 July 2019 | Published: 24 September 2019

\begin{abstract}
The Aam Admi Party (AAP; Party of the Common Man) was founded as the political outcome of an anti-corruption movement in India that lasted for 18 months between 2010-2012. The anti-corruption movement, better known as the India Against Corruption Movement (IAC), demanded the passage of the Janlokpal Act, an Ombudsman body. The movement mobilized public opinion against corruption and the need for the passage of a law to address its rising incidence. The claim to eradicate corruption captured the imagination of the middle class, and threw up several questions of representation. The movement prompted public and media debates over who represented civil society, who could claim to represent the 'people', and asked whether parliamentary democracy was a more authentic representative of the people's wishes vis-à-vis a people's democracy where people expressed their opinion through direct action. This article traces various ideas of political representation within the IAC that preceded the formation of the AAP to reveal the emergence of populist representative democracy in India. It reveals the dynamic relationship forged by the movement with the media, which created a political field that challenged liberal democratic principles and legitimized popular public perception and opinion over laws and institutions.
\end{abstract}

\section{Keywords}

Aam Admi Party; India; India Against Corruption; Janlokpal; political representation; populism

\section{Issue}

This article is part of the issue "Rethinking Representation: Representative Claims in Global Perspective", edited by Petra Guasti (Goethe University Frankfurt, Germany) and Brigitte Geissel (Goethe University Frankfurt, Germany).

(C) 2019 by the author; licensee Cogitatio (Lisbon, Portugal). This article is licensed under a Creative Commons Attribution 4.0 International License (CC BY).

\section{Introduction}

Recently there has been a lot of interest in understanding new ways of 'doing politics' in India. The 2014 general elections and the rise of Narendra Modi as Prime Minister from the right-wing Bharatiya Janata Party (BJP), it is argued, has ushered in a different style of politics in India, often described as populism (Gudavarthy, 2019; Jayal, 2016). The formation of the government in Delhi ${ }^{1}$ by the Aam Admi Party (AAP; Party of the Common Man) and the rise of its leader Arvind Kejriwal in the 2013 and 2015 state elections is also been argued to be another critical milestone in Indian democratic politics (Jayal, 2016; Roy, 2014). This party, as Stephanie Tawa Lama-Rewal (2019) mentions, claimed to have entered politics to "clean it [politics] from inside", to "change the rules" and to "make politics more honest". The AAP was founded as the political outcome of the India Against Corruption Movement (IAC), also known as the Janlokpal Movement that lasted for 18 months from 2010 to 2012. Janlokpal, in which Jan, a Hindi word meaning the 'people'. Lokpal, a Sanskrit word meaning 'caretaker of people', was used to stand for an Ombudsman body representing public interest. This word was coined by the

\footnotetext{
${ }^{1}$ Delhi is the national capital of India and is fully funded by the Union Government of India. It is a city as well as union territory of India. It has its own Legislative Assembly, the Lieutenant Governor, Council of Minister and Chief Minister. In 2013 Delhi Legislative Assembly Elections, all the three contesting parties, the BJP, the AAP and the Indian National Congress Party (INC) failed to get a majority and there was a hung Assembly. However, AAP formed a minority government with support of INC. They soon dissolved the government after 49 days claiming differences with INC. Delhi Legislative Assembly Elections were held again in 2015 and in this AAP won by a landslide majority winning 67 seats out of 70 seats and formed the government.
} 
IAC Movement to claim that this version of the body of Ombudsman were the true representative of the interest of the people. The movement demanded the passage of Janlokpal Act, which would institute an Ombudsman body to hold parliamentarians to account. The movement mobilized public opinion against corruption and was able to capture the imagination of the middle class in the process throwing up several questions of representation for public discussion.

This article draws from fieldwork conducted in 2014 and 2015 to trace the transformation in the media field after the 1990s and how that influenced the modes of contestations of social movements in contemporary India. By interrogating the process of the construction of political representation by the IAC Movement and the ways in which it influenced the dynamics of democratic politics in India, I develop two arguments. First, the emergence of IAC marked a significant moment that altered the political field in India and allowed for the rise of a populist language of social movements, which appealed more to authoritarian rather than democratic values. And second, that the media played a crucial role in driving this change.

\section{Political Representation and Media: Theoretical Framework}

In The Representative Claim (2010), Michael Saward built on Hannah Pitkin's classic model of representation in The Concept of Representation (1967). Pitkin's book, an influential theoretical work in the field of political representation, suggested representation was "substantive acting for others", where representing meant "acting in the interest of the represented" (Pitkin, 1967). This conceptualization limited the role of the represented and reduced it to passive acceptance and receiving information given by the represented. Saward argued that representation is dynamic and a two-way process where representations are constructed by making claims. Claim making lies at the core of his conceptualization. He stressed that the process of claim making is essentially performative in nature, where constituencies are created by claims made by actors, rather than being factual products of elections. Saward writes that "representing is performing, is action by actors and the performance contains or adds up to a claim that someone is or can be representative" (Saward, 2006, p. 302). Further, he writes that representative claims can only exist if 'audiences' acknowledge them in some way, therefore pointing to its dual effect, i.e., the 'subject' effect and the 'object' effect (Saward, 2006). The claim making process lies in the dynamics of the engagement of the subject and the object. The claims are made to represent a particular constituency and audience, while at the same time this very process of claim making is instrumental in constituting the audi- ence (Saward, 2006, p. 304). The creation of audiences is essential for representative claims to exist, thus pointing to the imperative role played by the media in this process. As Bourdieu mentions, that symbolic power constitutes the given by stating it, to act upon the world by acting upon the representation of the world. It does not reside in 'symbolic systems', but is defined in and by a definite relation that creates belief in the legitimacy of the words and of the person who utters them, and it operates only in as much as those who undergo it recognize those who wield it (Bourdieu \& Wacquant, 1992, p. 148). Media institutions gain significance as specialized agents of cultural production wielding the power to constitute representation. Media is a site of production, reproduction and circulation of facts that no one questions. It plays a critical role in the circulation of unconscious material and occupies a privileged position in the symbolic struggle to make things seen and believed (Bourdieu, Poupeau, \& Discepolo, 2008, p. 323).

In the context of India, media institutions have undergone several transformations in recent decades. There have been transformations in the print media as well as the electronic media (Jeffrey, 2000; Mehta, 2008). For both these forms the 1990s proved to be critical turning point. For the electronic media, 1990 saw the entry of satellite television in India. This completely altered the field of media and the politics that followed. The sociological journey of television can be plotted along some events that transformed television in India.

Rajagopal in his book, Politics after Television (2004), examines the rise of Hindu Nationalism with the Ram Jhanmabhumi Movement (birthplace of Lord Ram Movement) that led to the demolition of the Babri Masjid $^{2}$ in 1992. He argues that it was the screening of the televised epic of Ramayana by the state control electronic media channel Doordarshan that led to creation of a collective consciousness, which was essentially of Hindu Nationalism (Rajagopal, 2004). It was this Hinduised collective consciousness that the BJP leaders appealed to in the Ram Janmabhumi Movement, which had followed soon after. Television played this role not because of any intentional bias of the media towards a particular religion, but because of the inherent way the Ram Janmabhumi Movement was understood by the people within the media as well as outside it (Rajagopal, 2004, p. 172). Further to understand the audience that the televised epic of Ramayana was serving, he introduces the term 'split public'. He maintains that central to the split is the unfulfilled mission of secularism in a deeply divided Indian society. The creation of the Indian secular state after Independence, never really resolved the tension between orthodox Hindu and progressive nationalists, and maintained a split polity that on the one side retained an official secular public sphere and on the other side a heterogeneous popular culture which was

\footnotetext{
2 It was a mosque in Ayodhya, located in the state of Uttar Pradesh in India. Debates around it long existed in the popular discourse of the area that it was built by destroying a pre-existing temple of Lord Rama (Hindu God). On December 6th, 1992, the mosque was destroyed by the Hindu nationalist groups part of the Ram Janmabhumi Movement led by the right-wing party, BJP.
} 
still significantly Hinduised. The penetration of electronic media led to the blurring of the boundaries of this split, which was used to its advantage by the BJP in mobilizing massive Hindu sentiment around the Ram Janmabhumi Movement. They were able to convert this into electoral success in the next general elections, going on to form the government.

Rajagopal's work on television provides an important historical background to understand construction of popular political representation by media. Nirija Jayal (2016) on the other hand, builds on Bourdieu and Saward to interrogate the process of construction of political representation by political actors and its implications on the theory of representative democracy. In this she shows how the new forms of representation have slowly developed. The emergence of populist representation and Caesarist forms of representation have preceded traditional forms of representation, which have relied on aggregation of preferences or descriptive representation (Jayal, 2016, p. 173). Jayal shows the coming to power of the AAP in Delhi and the Narendra Modi-led BJP at the Union government in India to have relied on the populist and Caesarist forms of representation respectively.

Ajay Gudavarthy in his book, India after Modi: Populism and the Right (2019), examines the emergence of populism in India through a series of events in the regime of Narendra Modi's government post 2014 general elections. He writes that the turn to populism is a global phenomenon with specific characteristics. They include creation the 'people' as against an identifiable 'outsider'; a strong leader around whom all processes would revolve and finally symbols capable to merging 'facts' and 'fiction' and creating popular perception and narratives to establish and sustain the supremacy of the 'strongman' (Gudavarthy, 2019, p. 3). He highlights how perception is the key driver used to break the dichotomy of politics and policies and stripping laws of its social legitimacy. These phenomena have become visible in the last four years in India, where the Hindu-Muslim conflict has been used to create 'authentic people-the Hindu' in crisis against a perceived outsider the 'Muslim'.

This article builds on Jayal and Gudavarthy's argument to show how the anti-corruption movement that preceded the formation of the AAP engendered the political field that allowed for the new forms of representations to emerge. I use Saward's central concept of the dynamic, performative and constitutive nature of political representation to provide an insight into the IAC's construction of representative claims and constituencies, as well as the role played by the media in this process.

\section{IAC: The Beginning}

Between April 2011 and November 2012, the IAC captured the popular imagination in India, especially in Delhi, the national capital region of the country. The movement was set against the backdrop of several instances of large-scale political corruption by the ruling regime. Prominent amongst these was the case of corruption in the Commonwealth Games of 2010 (hosted by India from 3rd to 14th October in Delhi) that implicated the Chief Minister of Delhi, Sheila Dikshit. Several reports of gross irregularities and loss due to corruption surfaced. The loss to the exchequer was estimated to be close to Rs. 2,300 crores by the Comptroller and Auditor General of India. ${ }^{3}$

The movement began with a complaint filed in the form of a First Information Report (written document prepared by the Police on receiving information about the commission of a cognizable offence) against Sheila Dikshit at the Parliament Street Police Station ${ }^{4}$ on November 14th 2010 by Arvind Kejriwal. At the public event that followed, Kejriwal declared the launch of the 'movement against corruption' and demanded for passage of the Lokpal bill to put a stop to the widespread corruption in governance.

The central character of this movement, Arvind Kejriwal, was an officer in the Income Tax Department of the Government of India, who began his work by fighting corruption and bribery in Department itself. He set up camps outside the Income Tax office to assist people in seeking the redressal of their grievances without having to pay bribes. His work as an anti-corruption activist got him interested in the ongoing struggle that demanded for the citizens' Right to Information ${ }^{5}$ (hereafter RTI). He soon joined the RTI movement and also founded a nonprofit organization Parivartan ('Change'). The RTI Act was passed by the Parliament of India in 2005 (Jayal, 2007; Pande, 2007; Webb, 2010).

In the years after 2005, Kejriwal organized many campaigns that pushed for greater use of the RTI Act and ways to fight corruption in everyday governance. In most of the campaigns, media partnership played a critical role. Institutional collaborations with different media, both print and electronic, helped champion the use of RTI Act as an anti-corruption tool. The media relationships forged during these campaigns were later used to mobilize support for the IAC. The IAC campaign of 2010 was, however, a leap into a territory that generated much public interest. Starting off as an anti-corruption campaign, it soon snowballed into a country-wide move-

\footnotetext{
${ }^{3}$ The Comptroller and Auditor General of India is an autonomous body established by the Constitution of India to audit all receipts and expenditure done by the Government of India, the state (federal) government and all bodies and authorities substantially financed by the government.

${ }^{4}$ It is a prominent street near the Parliament of India and all surrounding area falls under the jurisdiction of this Police station. This is a high security zone in Delhi and remains under high surveillance round the clock.

${ }^{5}$ India inherited the Official Secrets Act of 1923 from its colonial past. Vide this legislation all government information was secret. It applied to government servants and citizens and made spying, sharing 'secret' information, unauthorized use of uniforms, withholding information, interference with the armed forces in prohibited/restricted areas, among others, punishable offences. If guilty, a person may get up to 14 years' imprisonment, a fine, or both. This Act prohibited sharing of any government information with citizens. The RTI campaign that began in the early 1990 s in the India, challenged this colonial act and demanded citizens' RTI. See Baviskar (2010), Jenkins and Goetz (1999) and Singh (2010).
} 
ment that threw the government off track. The movement's leaders made claims of representation, which finally led to the overthrow of the incumbent government and capturing of state power in the 2013 and 2015 federal elections of Delhi by the Kejriwal-led AAP.

\section{Claim Making and Political Representation: IAC and the Media}

Post the launch of the IAC on November 14th 2010 in Delhi, the movement held several other events in Delhi and in other parts of the country. All these were designed to be media events, where the messages were made available to be televised, circulated and consumed. One of my informants mentioned that the movement right from the onset foregrounded media as a central actor, and different aspects of the movement were designed accordingly (NK, 2014, Interviewed on November 13th). IAC, as the name suggests, claimed to represent the 'people of India' who were against corruption and demanded immediate action. The claim was strategically built, which in the process constructed both the representative as well as the represented, i.e., the constituency. A leading face is critical for the construction of a representative who will represent the constituency. A search for a 'face' ensued as recounted by another informant (SM, 2014, Interviewed on September 16th). Until now, all anti-corruption campaigns by Kejriwal were led by him, but for this one, he wanted a more 'representative face', one that would have a mass appeal (NK, 2014, Interviewed on November 13th). Kejriwal approached religious and spiritual leaders such as Baba Ramdev, a yoga guru and spiritual leader, and Sri Sri Ravi Shankar, a spiritual leader and founder of Art of Living Foundation, both leaders having huge mass support and following amongst the urban elite and middle class population across the country and overseas. Both these personalities were engaged in the initial protests and events. The IAC successfully tapped into the followings of these two spiritual leaders to build its initial support base in Delhi and other urban areas. The large number of volunteers of the Art of Living Foundation in Delhi and other parts of the country formed the initial backbone for the movement. However, later, with increasing popularity many others joined. After the initial boost, IAC soon distanced itself from these two leaders but continued to draw on their support. However, Kejriwal continued to look for a 'face' to lead the campaign; the movement needed a 'face' that could appeal to large section of the population, a non-elite yet someone who could not be dismissed by the middle class and the elite (NK, 2014, Interviewed on November 13th).

\subsection{Making of the 'Representative'}

Anna Hazare was a self-proclaimed Gandhian, known to have made significant changes in terms of good governance in a small village, Ralegaon Siddhi, in the state of
Maharashtra. He had contributed to anti-corruption activism in Maharashtra and had been on hunger strike to pressure the Maharashtra government to implement the RTI Act. He had been awarded the Padma Bhushan for his efforts (the third highest civilian award given by the Republic of India for distinguished service of a high order). Though regionally significant, he was not well known to the national media. Kejriwal was looking for a face who could lead the campaign. Anna Hazare was someone whose image could be popularised by the national media. The narrative that was built around Hazare projected him as a pure and selfless old man, a true 'nationalist', ready to lay down his life for the nation. Kejriwal and his team built a twofold strategy. First, to create an identity of Anna Hazare and establish him as the leader of this anti-corruption campaign. Second, to create the constituency, 'the people', for Anna Hazare to represent (BK, 2014, Interviewed on August 6th; NK, 2014, Interviewed on November 13th; SM, 2014, Interviewed on September 16th).

For the first, the image of Mahatma Gandhi was borrowed. Saward writes that representative claims that resonate amongst the audience are made from 'ready mades', i.e., from existing terms and understandings that the audience recognize. The style, timing and content of a representative claim has to link with a contextual framework that is familiar. The claim has to repeat the familiar as well as add something new for it to be acceptable to the audience (2006, p. 303). The narrative that was woven around Anna Hazare was that of a 74 years old man, who had given all his life to serve the nation as part of the Indian Army. He owns nothing, just a plate to eat and a bed to sleep on, he stays in one room of a temple, has no bank balance, no car and no personal property, has no affiliation with any political party, nor any desire for high titles. He has been fighting for the last 20 years against corrupt and anti-social people, his efforts have forced 6 corrupt ministers to resign and 400 corrupt officials were dismissed from their jobs. During his fight, the government had jailed him, but he wore that as a badge of honor. He believed that he has one life to serve the country and he cannot bear to see injustice been done, and was ready to give up his life fighting for the welfare of people of his country. He was determined to uproot corruption. He was ready to fast unto death to protest against government inaction on fulfilling the demand for a strong Lokpal Act'. The narrative was of him being an undisputable leader similar to Mahatma Gandhi who had emerged to lead the country out of the dark days of corruption was created and reinforced at every stage. The link with Mahatma Gandhi also sought to revive the anti-colonial nationalism narrative and draw parallels of this movement with independence struggle of India. Mahatma Gandhi had fought against the colonial government to free India and Anna Hazare would fight the corrupt government to free India from the shackles of corruption and darkness. Slogan and visuals saying Bhrashtrachar Bharat Choro (Corruption 
Quit India) modeled around the historical movement of Quit India Movement of August 1942 or Kale Angrezo Bharat Choro (Black Englishmen Quit India) were indicative of the how heavily the movement borrowed from independence movement of India. And in this narrative Hazare was the self-claimed 'dusra or second Gandhi' fighting 'aazadi ki dusri ladhai' ('second freedom struggle'; Pinney, 2014).

Political representation is performative in nature, and a lot of that performance is played out through visuals and actions that serve to make the claims real (Saward, 2006). Consistent and powerful visuals were created to build the image of Anna Hazare on the existing repertoire of visuals of Mahatma Gandhi. The movement used, posters, banners, national flag, stage backdrops, slogan and all other communication avenues to link Anna Hazare to Gandhi and to the independence movement. All events repeatedly used Anna's photo and juxtaposed it with portraits of Gandhi in the backdrop. Use of Gandhi Topi or Gandhi Cap, named after Mahatma Gandhi and used during Independence movement, use of slogans like, 'Anna nahi, yeh aandhi hain, Desh ka doosra Gandhi hain' ('This is not Anna, but he is like a storm, he is the second Gandhi of the country') served to reinforce the linkage (Pinney, 2014; Webb, 2015). The cap was sold widely at the protest sites and had 'We want Janlokpal' and 'I am Anna', written on either side. The display of large national flags and nationalist slogans at protest sites became an important symbol linking 'nationalism' to this movement. The campaign used several props to sustain the visual continuity of the representations.

In addition to the caps and posters, careful designing of backdrops of the stage set up at the protest events also kept the message consistent and uniform. Further the claim of IAC to be representing the 'national voice against corruption' was constructed through several tropes and in this the assertion made by the media to be speaking on 'behalf of the nation' was critical (Jayal, 2016). For construction of the media narrative, first, the movement had a name, which was distinct, and claimed representation of the entire nation to be part of this campaign. Second, it delivered a solution that was chosen by the people themselves, that is, the jan-lokpal or the people's lokpal, where 'Jan' meaning 'people'. This contested claims of any other drafts of the Lokpal bill to be representative vis-à-vis the 'people's draft' - the Janlokpal. During the deliberation on the Lokpal bill, many drafts were suggested. But it was only the Jan-Lokpal bill drafted by the IAC that claimed to be 'representing the interest of the people' and publicly dismissed all other drafts. The channels showed Kejriwal burning the government draft of the Lokpal bill by claiming it as 'jokepal' rather than 'lokpal'. The claim of representation was established by claiming that thousands of people had contributed to the drafting process of the Janlokpal bill. Email ID and helpline numbers were widely publicized on media platforms asking people for their suggestions. This also acted as a primary vehicle for the movement to connect with its constituency and give them the feeling of been heard and participated. Third, the campaign had a distinct logo, which was used consistently for all posters and all communication material. Fourth, the campaign had a leading face, Anna Hazare, who claimed to represent the values of Mahatma Gandhi. Like Gandhi, Hazare also was an ardent follower of non-violence and he chose classic Gandhian tools of protest-that is anshan (hunger strike) - to fight the 'azaadi ki doosri ladai' (second struggle for independence). To reiterate this image further, at the beginning of each protest, Anna Hazare was seen visiting Mahatma Gandhi memorial at Rajghat (located in Delhi). He was seen spending time praying for inspiration and power for his fight. Careful attention was paid by IAC on image-engineering, where Hazare would be seen offering prays, sitting on green grass on a spotless white sheet wearing spotless white dhoti and kurta! A lot of attention was given to the actions of Hazare and key faces of the movement, and also to how those actions were 'perceived' by the media.

\subsection{Making of 'Represented'}

Next, if political representation is understood as a 'framing' process that is dynamic in nature, then claims define the contours of the frame and encode the representation while simultaneously also influencing how and who it will seek to represent, i.e., its constituency (Saward, 2006). Essentially saying that by the very act of claiming representation of a certain group, we shape the identity of that group. The IAC campaign used 'corruption' as the hinging idea to define the identity of the group. The movement claimed that if you are against corruption then you are part of IAC.

'Corruption' is a catch-all term and emerged into prominence in 1990s within the international development discourse dominated by the paradigm of good governance. Studies show that corruption appeared in the forefront of policy discussion of international donor agencies, especially the World Bank, during this time. These studies argue that the obsession with corruption was prompted by the need of international donors to explain the failure of structural adjustment policies. Attention to corruption has grown in tandem with the policies of liberalization, privatization and decentralization. In this, corruption in state apparatus forms the basis of demanding reduction in state power and making way for privatization and rule of market (Harrison, 2006; Schmitz, 1995; Szeftel, 1998). Now, if we understand the media to be a significant vehicle for entry of market in the society, then there is a natural alliance of the media and the agenda that highlights corruption of the state (Rajagopal, 2004, p. 35). Moreover, corruption by definition means different things in different contexts. Two broad categories can be used to understand corruption'political corruption' operating in the realm of highest level of government and 'bureaucratic' or petty corruption, experienced at the lowest level of government ex- 
perienced by citizens in everyday interactions with the state. Within this, there can be 'experienced' corruption and 'perceived' corruption (Harrison, 2006).

Kejriwal, during his early years as anti-corruption activist, targeted petty corruption in everyday transactions with the state. His action drew from the premise that the act of exchange of information from the government to the people was sufficient to address 'corruption' and to correct the erring behavior of the state. The IAC Movement, however, straddled both the aspects of corruption, i.e., political corruption and bureaucratic corruption and often used them interchangeably. It also used language and strategies that collapsed the distinction between 'experienced' corruption and 'perceived' corruption. The depiction of real life stories in a form of short videos narrating the experience of corruption of a particular individual and how that had impacted his/her life was instrumental in shaping the perception of corruption in general and in building a perception that corruption pervaded all transactions of the state (see Al Jazeera English, 2011). It created a sense of crisis in governance, which could only be addressed by ensuring flow of information from the state to its people and by creating an all-powerful body, in the form of an Ombudsman, the Lokpal. The media played a significant role in creating an atmosphere of crisis in governance and in stripping the ruling government of its legitimacy. It was instrumental in construction of a narrative of political and bureaucratic corruption by translating 'perceived' corruption to 'experienced' corruption. Dedicated programing on government failure and round the clock coverage of protest created a dramatic image of the movement and established Hazare as the true 'savior'. This also helped in construction of a community that had only one nebulous identity-that they were against corruption. The mediatized campaign not only used corruption as a commodity to transform the field of interaction of the citizen, it also altered the state and society relationship, making the boundaries porous.

\subsection{Creation of 'Represented' through Direct Action}

Further, if creation of the identity of the represented is to be understood in electoral terms, then what we are looking at is the process by which the representative claims made by the IAC worked to construct an electoral constituency. IAC used direct action where it engaged its constituency to take up acts targeting the state. For instance, a movement pamphlet/handbill of IAC, titled 'Let's Form Vote Banks Against Corruption' circulated amongst the volunteers of IAC mentions:

The political parties and candidates win by very narrow margins. In Delhi, almost 110 candidates won by less than 1000 votes in last municipal elections. This means that if 500 votes were polled differently, it could have changed election results...if 200 families in a ward come together and decide to vote as a block, they can change the electoral results of a ward. They can force all candidates to agree to their demands. Together, they can't make anyone win, but they can make anyone lose elections. Can we get such people together in each ward and form a "vote bank against corruption" in each ward? (IAC, 2011a)

The handbill instructed people to write to their elected representative threatening them to either pass the Janlokpal bill or else they will not vote for him the next time. Similar to the instruction given in the handbill, Hazare and Kejriwal in many other instances demanded 'direct action' from their constituency. For instance, people were asked to protest in front of residences of elected representatives demanding their support to the passage of the Janlokpal bill in the Parliament or else they would continue to demonstrate. The Facebook pages of the IAC urged people to send emails to the Prime Minister, Law Minister, Home Minister and others, demanding action on the demands of the movement. Pre-written text was provided to supporters to use in the emails stating that that as a responsible citizen of the country they were concerned about the health of fasting Anna Hazare, who was the 'Greatest Social Reformer India has ever seen' and that his demands were 'extremely beneficial to the future of India'. The email would close with a threat by the citizen to fast unto death if the government failed to accept the demands (IAC, 2011b).

The IAC constituency was however not only created through such direct actions. As Rajagopal in his analysis of the transformation of politics after television explains that television has the power to construct 'communities of sentiment' (2004, p. 6). Television brings public events into a private space. This allows the individual viewer to develop an imaginative reconstruction of themselves as being enmeshed in the televised event and to reflect the sentiments expressed in it. $24 \times 7$ live streaming from the IAC protest sites enabled the formation of these 'communities'. Television channels showed people in large numbers joining the protest and with every day that the protest was live streamed the turnout increased. Channels covering the protests ran messages such as 'jaan salaab' (a sea of people), 'janta ka hujum' (a spirited crowd has arrived) depicted mass support to the movement. The telecast of the protest and the accompanying messages were instrumental in creation of a 'nationalist' sentiment that further provoked others to join. 'Communities of sentiments' were constructed, which were further consolidated by social media interactions. Facebook pages allowed exchanges between individuals who were watching the protest on television in their private spaces, to share sentiments through short emotive messages about the 'nation'. These interactions further deepened these associations and shaped collective identities. During this time, the discourse of the movement evoked several collective identities-'nation', 'country', 'the people', 'movement', 'civil society', 'us vs them'. All these communities were constructed in the 
minds of the viewers and supplemented by the virtual interactions on the social media platforms. The experience of those attending the protest sites was similarly mediated as they consumed the televised image and messages of the movement via mobile devices. It is clear that the direct actions demanded by the IAC Movement on its Facebook pages helped to establish these collective identities and 'communities of sentiment' from which the constituency of the IAC movement was formed.

Niraja Jayal (2016), in her analysis of representative claims categorized this form of politics to be 'populist', where the legitimacy stems from 'speaking on behalf of the people'. This straddles between two forms of politics-one that promotes pragmatic politics that follows the rule of law and upholds sanctity of institutions, while the other is redemptive in nature and is grounded in power of the people. The IAC makes this dynamic visible. The movement demanded that a law be legislated by a process that refused to acknowledge the legislative framework set out by the Constitution of the country. It was dismissive of the Parliament, the Judiciary and all political leaders. It called for total revolution by provoking people to ambush elected representatives and threatened government with mass hunger strikes. These were indicative of its redemptive form of politics. Politicians and offices of elected representatives were rendered illegitimate and Parliament made into an object of protest. The movement made constant reference to the 'streets that belonged to the 'people' as being a more legitimate site than the Parliament for vetting of the Lokpal bill' (Jeelani, 2011). Also, populist forms of politics put a lot of emphasis on direct democracy-i.e., referendums through text message, mails, or opinion polls. IAC constantly engaged its constituency through 'direct action'. In this, the citizen is rendered not only as a participatory being taking decisions and actions into his/her own hands, but also as distrusting and suspicious of the other and with the potential for vigilantism. He or she is also making judgments and subjecting the government and the 'other' to constant scrutiny. Activities such as targeting covert "sting" video operations at public officials alleged to be corrupt provoked and publicly established the legitimacy of vigilantism. As Amit Bhaduri (2011) writes, the very essence of representative political democracy is that it restricts the political participation of its citizen to choosing representatives in elections. But when direct action by citizens is provoked then it gathers momentum and erupts with elected representatives losing their legitimacy. Such circumstances make way for 'heroes' who can step into provide a solution and show the way forward. An example of this from the IAC Movement is the moment IAC leaders targeted Sheila Dikshit, the then Chief Minister of Delhi, and accused her of corruption as a retaliatory action; Anna Hazare was arrested from his residence in the early hours of the morning on August 16th, 2011. The Police arrested him giving flimsy grounds that he was threatening to sit on an indefinite hunger strike demanding the Janlokpal bill. This impulsive behavior of the government was projected by IAC to be indicative of loss of legitimacy and power of the political class. Bhaduri (2011) explains that the impatient attitude of 'now or never' of the people that followed post the arrest of Hazare was not just due to history of years of inaction of the government, but an interpretation that there has been manipulation of procedures to protect the corrupt. In the crisis that ensued, Anna Hazare emerged as an undisputable leader of the anti-corruption crusade (Bhaduri, 2011).

\subsection{Media: The Arbitrator of Change}

Rajagopal (2004), writes that politics to a great extent is carried out through the means of communication. The emergence of electronic media enabled institutionalized production and circulation of images and symbols, which displaced and transformed the boundaries of the political sphere. The media transformed the political sphere by its ability to produce and circulate images and symbols and make it available for consumption in the private space of our homes. Through media various unrelated events and temporal realities were stitched together into a single communicative event. The media campaigns on anticorruption by Kejriwal valorized 'corruption' as an act of the state against its citizens and 'information' as a currency that can be exchanged for the value of better governance. Rajagopal (2004) writes that television works in parallel, and interlinked, with the economy, where it is active in the material and symbolic reproduction of capitalist relations. Television works to commodify and assign value to abstract concepts and ideas that can be exchanged and reproduced through the circuit of its circulation. The media campaigns served to commodify 'corruption' in a way that could be reproduced and circulated.

In the IAC Movement the discourse of corruption was carefully yoked within a cultural and symbolic context that resonated with the Hinduized media. The projection of Anna Hazare, as a symbol of austerity, of purity served to emphasis an abstract Brahminical concept of Hinduism that asserts its Hindu identity and at the same time is inclusive of the 'other', thus the symbolic presence of the Muslim clerics and Archbishop of Delhi. The ritualistic morning prayers and all day bhajans at the protest sites with Indian flags in the background set the stage for the resurgence of a new form of Hindu Nationalism.

I use Rajagopal's work to argue that the IAC Movement also marked a significant moment in the transformation of the media and the political field it produced. The populist representations of IAC Movement created by the media where it liberally borrowed Hindu symbols on the one hand and nationalist images on the other, paved the way for a resurgence of Hindu Nationalism. The Hindu identity was implicitly evoked through symbolic representations, such as the depiction of Bharat Mata (Mother India) as a Hindu Deity and the use of slogans such as 'Bharat Mata ki Jai' ('Long live 
Mother India'). Hazare, along with been projected as the new avatar of Gandhi, was also referred as aj ke Krishna or Krishna of today (Hindu God) and other such Hindu figures in the media saturated discourse of the movement (Pinney, 2014). Further, singing of Bhajans (prayers) at the protest sites were some of the symbols instrumental in consolidating the Hindu identity of the movement. Also, the visible presence of people like Baba Ramdev made the connection stronger. These implicit connections to Hindu identity was explicitly balanced with symbolic activities like celebration of Ramadan and Eid at the protest site along with celebrating the Hindu festivals like Jan-Mashtami-the festival celebrating the birth of Lord Krishna during the August protest of 2011 at Ramlila Maidan.

The claim making process of IAC constituted a constituency that was amorphous-essentially urban, middle class, Hindu, vigilant, distrusting of politicians and Parliamentary processes. And as Jayal (2016) points out that populist politics does little to really encourage participation of its constituency. Instead, it directs the emotional fervor to establish a leader, who has a personalized and centralized style of leadership. Kejriwal established himself as the leader and consolidated the power of popularity of the IAC Movement with the formation for the AAP in 2012. But as Stephanie Tawa Lama-Rewal (2019) explains the coming to power of AAP in Delhi was also tormented with contestations. First, its forming the minority government by taking support from Congress whom it had overthrown; second, Kejriwal resigning within 49 days of taking to office; third, Kejriwal publicly apologizing for his resignation claiming that it was his biggest mistake; fourth, its public contestation and verbal battles with the Lieutenant Governor of Delhi leading to a paralysis of governance in Delhi; fifth, its open battle with the Municipal Corporation of Delhi and lastly its dramatic split with Yogendra Yadav and Prashant Bhushan, the key leading faces of the movement. All these worked to erode the public image of Kejriwal as the leader of the nation. He had lost the legitimacy to 'represent India' that he had built in the last couple of years. By then Narendra Modi and BJP had emerged to represent the rising Hindu nationalist constituency and was successful in occupying the vacant space left behind by Kejriwal, as larger than life 'hero'.

As Gudavarthy (2019) mentions through 2014, a larger than life personality was created in the person of Narendra Modi, which served to position him as defending Hindus and the Hindu national identity. It was further strengthened through his fights against Pakistan and the perceived 'other' within. The IAC Movement, that preceded the rise of Narendra Modi, showed similar characteristics. The representative claims created an authentic community, i.e., 'the people' who were against corruption, second, it constructed the perception of governance crisis and calling for the 'direct action' and involvement of citizens in drafting laws instead of elected policy makers. For instance, Hazare and Kejriwal claimed that the streets, in belonging to the 'people', were more legitimate than the Parliament, the home of 'corrupt government'. Further the use of nationalist symbols within the mediatized movement narrative served to stir up the existing perception of Hinduised nationalism. The movement built popular perceptions and authoritarian demands that undermined laws and institutions and paved the way for the emergence of populism in India.

\section{Conclusion}

In this article, I use the theoretical framework provided by Michael Saward to analyze the construction of political representation of the IAC Movement that unfolded in India during 2010-2012. The trajectory of the movement is traced to understand how the dynamics of the representation was created. I draw from this to make the following conceptual points.

First, considering political representation to be a twoway process of mutual exchange between the representative and the represented, the IAC Movement makes visible the construction of the representative and the represented. The image of Anna Hazare as 'strong' leader of the movement was constructed using various media tropes. The movement revolved around his personality and the virtues surrounding it. The movement also used symbols that merged perception with experience, i.e., merging facts and fiction. The representative claim making processes through this resulted in creation of a constituency that essentially transformed to become a Hindu nationalist identity.

Second, it made visible how the process of claim making often created a competitive environment to see one claim succeed over the other in order to claim authenticity of representation. That is, the IAC often deliberately pitted one claim against the other, such as the claim of Jan-Lokpal was pitted against Lokpal; 'Aam Admi'common man-pitted against the concept of Khas Admi or the elite and privileged; civil society pitted against sarkari civil society-with the IAC being the true representative of civil society, rather than a civil society that was co-opted and captured by the government. Saward (2006) mentions that the space of representation is contested; I argue that it is not only contested, with competing claims operating to claim attention of the constituency, but that deliberately orchestrated contestations also take place in order to further entrench the link between the representative and represented.

Lastly, it made visible how the transformation in the representative claim making is linked to the transformations in democratic politics and the leaderships that emerge within them. The literature on populism indicate how populist representations have emerged and built on the traditional political representations that either been aggregation of preferences or have been descriptive representations (Jayal, 2016). Therefore, the tracing of the trajectory of the claim making process is indicative of the nature of the democratic processes it engendered. 


\section{Acknowledgments}

I would like to thank Stephanie Tawa Lama-Rewal and the Centre for South Asian Studies (CNRS-EHESS), Paris for their support to my work. I would like to acknowledge my friends Anupama Ramakrishnan, Rukmini Barua and Martin Webb for their valuable input to this article.

\section{Conflict of Interests}

The author declares no conflict of interests.

\section{References}

Al Jazeera English. (2011). India anti-corruption protest continues. YouTube. Retrieved from http://www. youtube.com/watch?v=Q7loGdtWXGk

Baviskar, A. (2010). Winning the right to information in India: Is knowledge power? In J. Gaventa \& R. McGee (Eds.), Citizen action and national policy reform (pp. 130-146). London: Zed.

Bhaduri, A. (2011). Corruption and representative democracy. Economic and Political Weekly, 46(36), 15-17.

Bourdieu, P., Poupeau, F., \& Discepolo, T. (Eds.). (2008). Political interventions: Social science and political action. New York, NY: Verso Books.

Bourdieu, P., \& Wacquant, J. D. L. (1992). An invitation to reflexive sociology. Chicago, IL: The University of Chicago Press.

Gudavarthy, A. (2019). India after Modi: Populism and the right. Delhi: Bloomsbury Publishing.

Harrison, E. (2006). Unpacking the anti-corruption agenda: Dilemmas for anthropologist. Oxford Development Studies, 34(1), 15-29.

India Against Corruption. (2011a). Let's form vote banks against corruption [Pamphlet]. New Delhi: India Against Corruption.

India Against Corruption. (2011b, April 1). Send letter to PM, Law Minister and others for Jan Pal bill [Facebook status update]. Retrieved from https://www. facebook.com/notes/india-against-corruption/sendletter-to-pm-law-minister-and-others-for-jan-lokpal-bill/165318140190081

Jayal, N. G. (2007). New directions in theorising social accountability? IDS Bullentin, 38(6), 105-112.

Jayal, N. G. (2016). Contending representative claims in Indian democracy. India Review, 15(2), 172-195.

Jeelani, M. (2011, September 1). The insurgent: How Arvind Kejriwal, the architect of Anna Hazare's anticorruption campaign, brought the rage of an indignant nation to the government's door. The Caravan. Retrieved from https://caravanmagazine.in/ reportage/insurgent
Jeffrey, R. (2000). India's newspaper revolution: Capitalism, politics and the Indian language press. New Delhi: Oxford University Press.

Jenkins, R., \& Goetz, A. N. (1999). Accounts and accountability: Theoretical implication of the right-toinformation movement in India. Third World Quarterly, 20(3), 603-622.

Mehta, N. (2008). India on television: How satellite news channels have changed the way we think and act. New Delhi: Harper Collins.

Pande, S. (2007). The right to information and societal accountability: The case of the Delhi PDS campaign. IDS Bullentin, 38(6), 47-55.

Pinney, C. (2014). Gandhi, camera, action! India's 'August spring'. In P. Werbner, M. Webb, \& K. Spellman-Poots (Eds.), The political aesthetics of global protest: The Arab spring and beyond (pp. 177-192). Edinburgh: Edinburgh University Press.

Pitkin, H. F. (1967). The concept of representation. Berkeley, CA: University of California Press.

Rajagopal, A. (2004). Politics after television: Religious nationalism and the reshaping of the Indian public. Cambridge: Cambridge University Press.

Roy, S. (2014). Being the change. Economic \& Political Weekly, 49(15), 45.

Saward, M. (2006). The representative claim. Contemporary Political Theory, 5(3), 297-318.

Saward, M. (2010). The representative claim. Oxford: Oxford University Press.

Schmitz, G. J. (1995). Democratization and demystification: Deconstructing "governance" as development paradigm. In D. Moore \& G. Schmitz (Eds.), Debating development discourse: Institutional and popular perspectives. London: Macmillan Press.

Singh, S. (2010). The genesis and evolution of the right to information regime in India. In Towards a more open and transparent governance in South Asia regional workshop (pp. 27-29). New Delhi: Indian Institute of Public Administration.

Tawa Lama-Rewal, S. (2019). Political representation in the discourse and practices of the "Party of the Common Man" in India. Politics and Governance, $7(3)$, 179-188.

Szeftel, M. (1998). Misunderstanding African politics: Corruption and the governance agenda. Review of African Political Economy, 25(76), 221-240.

Webb, M. (2010). Success stories: Rhetoric, authenticity, and the right to information movement in north India. Contemporary South Asia, 18(3), 293-304.

Webb, M. (2015). Contemporary Indian anti-corruption movements and political aesthetics. FocaalBlog. Retrieved from http://www.focaalblog.com/2015/ 04/23/martin-webb-contemporary-indian-anticorruption-movements-and-political-aesthetics/ 


\section{About the Author}

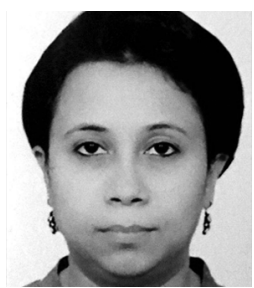

Aheli Chowdhury is a Development Professional based in Delhi. She holds a PhD in Sociology from Delhi School of Economics and her work explores intersectionality of media and social movements in India. She works amongst urban poor to facilitate their rights to education and governance and has been involved with several rights-based campaigns, including the National Campaign for People's $\mathrm{RTI}$ in India. She is also actively engaged with and studies policy gaps in social accountability and service delivery. 